
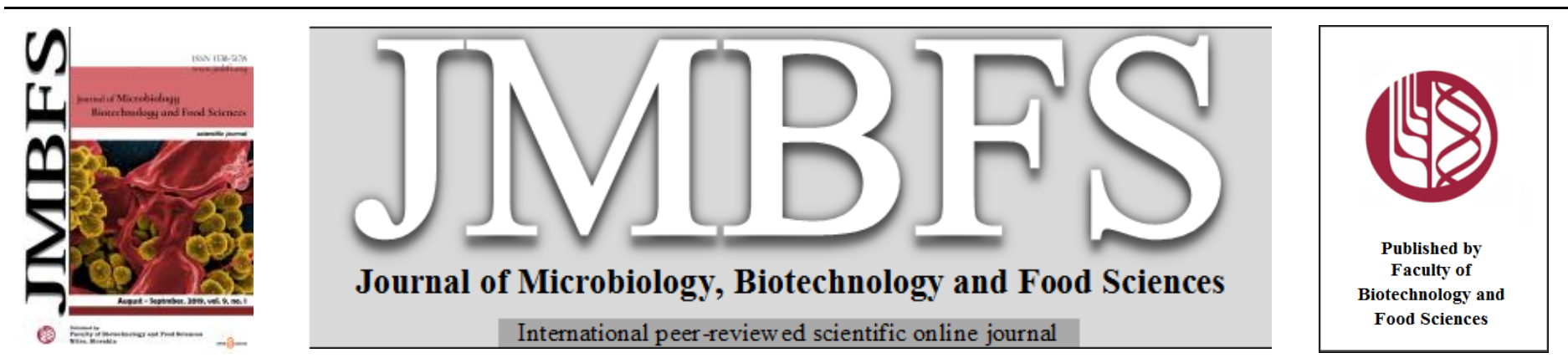

\title{
OPTIMIZATION OF TOTAL SOLUBLE PROTEIN PRODUCTION BY Trametes sp. isolate B7 AND ENZYMATIC DEGRADATION OF SYNTHETIC DYES
}

\author{
Benjamin Vandelun Ado $*^{1}$, Abiodun Anthony Onilude ${ }^{2}$ Tivkaa Joseph Amande ${ }^{3}$ \\ Address(es): Benjamin Vandelun Ado, \\ ${ }^{1}$ Department of Microbiology, College of Science, Federal University of Agriculture, PMB 2373 Makurdi, Benue State, Nigeria, +2348065591916 \\ ${ }^{2}$ Department of Microbiology, Faculty of Science, University of Ibadan, Ibadan, Oyo State, Nigeria. \\ ${ }_{3}^{3}$ Department of Microbiology, Faculty of Science, University of Uyo, Uyo, Akwa Ibom State, Nigeria.
}

*Corresponding author: benjaminado@yahoo.com ; ado.benjamin@uam.edu.ng

doi: 10.15414/jmbfs.2019.9.1.99-103

ARTICLE INFO

Received 10. 11. 2018

Revised 17.3. 2019

Accepted 21.3. 2019

Published 1. 8. 2019

Regular article

OPEN $\partial_{\text {ACCESS }}$

\begin{abstract}
Filamentous fungi as a source of bioproteins for biotechnological applications are preferred over bacteria and yeasts due to their excellent yield and total volume of production. Fungal laccases are useful because of high redox potentials and low substrate specificity to xenobiotics. However, challenges for large-scale utilizations are low enzyme yield and high cost of production. Saw-dust of Terminalia superba abounds locally and was utilized as alternative substrate for production using various optimization processes. Trametes sp. isolate B7 was isolated and identified using molecular techniques. Optimum $\mathrm{pH}$ and temperature for total soluble protein (TSP) and laccase activity were $\mathrm{pH} 5.0(3.6 \mathrm{mg} / \mathrm{mL}, 2356 \mathrm{U} / \mathrm{mL})$ and $25^{\circ} \mathrm{C}(2.3 \mathrm{mg} / \mathrm{mL}, 2395 \mathrm{U} / \mathrm{mL})$, respectively. Enhanced production of TSA occurred in $\mathrm{Cu}^{2+}(2.70 \mathrm{mg} / \mathrm{L})$ and $\mathrm{Ca}^{2+}(2.50 \mathrm{mg} / \mathrm{L})$ at $3 \mathrm{mM}$. Laccase activity was recorded at $1-2 \mathrm{mM} \mathrm{Cu}^{2+}(2379$ $\mathrm{U} / \mathrm{mL})$ and $3-4 \mathrm{mM} \mathrm{Ca}^{2+}(2385 \mathrm{U} / \mathrm{mL})$. Productions of TSP and laccase activity were higher using ammonium sulphate and ammonium chloride respectively. Glucose induced the best TSP and laccase activity of $3.6 \mathrm{mg} / \mathrm{mL}$ and $2395 \mathrm{U} / \mathrm{mL}$ respectively. TSP and laccase activity were best on day $14(3.6 \mathrm{mg} / \mathrm{mL})$ and day $18(2395 \mathrm{U} / \mathrm{mL})$ respectively. Percentage degradation of synthetic dyes using crude laccase $1000 \mathrm{U} / \mathrm{mL}$ (and $2000 \mathrm{U} / \mathrm{mL}$ ) were: Remazol Brilliant Blue Royal 100\% (77\%), Phenol red 28\% (36\%), Congo red 75\% (64\%), and Malachite green $62 \%$ (28\%) respectively. The ability of laccase to degrade Phenol red and other synthetic dyes without using enzyme mediators made it a valuable tool for biotechnological applications.
\end{abstract}

Keywords: Trametes sp., Total soluble protein, Laccase activity, Optimization, Synthetic dyes, Enzymatic degradation

\section{INTRODUCTION}

Filamentous fungi are efficient sources for extracellular production of proteins both enzymic and non-enzymic, which are applied in a wide variety of processes in the fields of environment, industry and food biotechnology. Total soluble proteins as secondary metabolites are usually induced by stress factors including limited carbon and nitrogen levels among others in media formulations. They include ligninolytic enzymes like laccases, peroxidases and oxidases, hydrolytic enzymes such as pectinases, cellulases and hemicellulases and degradative enzymes such as proteases, amylases (Mtui, 2009). Laccases of fungal origin are more useful in industrial and biotechnological applications because of their catalytic properties, high redox potentials and low substrate specificity for synthetic dyes, phenols, polyphenols, aryl diamines, anilines, hydroxyindols, methoxy substituted phenols, benzenethiols, inorganic/ organic metal compounds and many other xenobiotics (Kunamneni et al., 2008).

Studies have shown that some Wood Rot Fungi (WRF) contain all three classes of ligninolytic enzymes, whereas others may contain only one or two of these enzymes (Poojary et al., 2012). Trametes versicolar, Pleurotus ostreatus, Pleurotus eryngii, Agaricus blazei, and Clitocybe maxima are suitable for largescale production of laccases while Ganoderma lucidum is an efficient producer of laccases, Mn oxidizing peroxidases and lignin peroxidases (Aftab and Ahmad, 2015). Martins et al. (2011) also reported that fungi such as Phanerochaete chrysosporium and Trametes versicolor, Trametes hirsuta, Bjerkandera adusta, Irpex lacteus, Dichomitus squalens, Funalia trogii, Pycnoporus sanguineus, Phlebia radiata and Daedalea flavida are of biotechnological importance, because they carry out enzymatic degradation of a wide variety of recalcitrant compounds including synthetic dyes resulting in detoxification and mineralization.

Globally, more than 100,000 dyes are commercially available with an annual production of over $7 \times 10^{5}$ tonnes of the dyestuffs (Itodo et al., 2017). Extensive utilization of these occur in diverse industrial processes such as textile and leather dyeing, paper printing and coloured photography, cosmetics, food, pharmaceuticals as well as additives to petroleum products (Gonawala1 $\boldsymbol{e t}$ al., 2014). As a result, approximately $10-15 \%$ of used dyes are released into the environment as wastewater which contaminates surface water, soils and underground water by infiltration (Hassaan and Nerm, 2017). Among the many classes of synthetic dyes used in the textile and dyeing industries, triphenylmethane group of dyes such as crystal violet and malachite green are the largest and most commonly used in almost every type of application. Most of the synthetic dyes are characterized by high stability in presence of light and high temperatures, and are fast to detergents and attacks of microorganisms. In addition, they exist in wide arrays of colours along with the ease and low cost of synthesis compared to natural dyes (Roushdy and Abdel-Shakour, 2011).

However, many synthetic dyes are toxic, carcinogenic or prepared from known carcinogens or other aromatic compounds that may cause harm to humans, animals or other forms of aquatic resources (Songserm et al., 2012). For instance, Malachite green which is employ in dyeing of jute, leather, silk, cotton, wool and ceramics is also a potent antiprotozoan and antifungal. Nevertheless, it is highly poisonous to cells of mammals and has been implicated in promoting the formation of hepatic tumors in rodents as well as reproductive abnormalities in rabbits and fish. When reduced to leucomalachite green, it may persist in tissues of edible fish for extended periods through bioaccumulation, and therefore it is of public health concern in terrestrial and aquatic habitats (Fallah and Barani, 2014). The structural similarity of malachite green to other carcinogenic triphenylmethane dyes also raises suspicion of carcinogenicity. Crystal violet on the other hand has been identified as a thyroid and liver carcinogen in rodents while pararosaniline is a bladder carcinogen in humans (Suwannawong $\boldsymbol{e t}$ al., 2010).

Aromatic compounds and their derivatives are pollutants of high priority because they impact negatively on aquatic organisms even at low concentrations. Treatments of these pollutants can be achieved using conventional methods. However, these methods are expensive, time consuming and often lead to formation of toxic residues (Villegas $\boldsymbol{e t}$ al., 2016). Several studies have reported the decolourization of synthetic dyes by fungal species using laccase as the main 
enzyme during the process (Songserm et al., 2012). The use of laccase an oxidoreductive enzyme in biological treatment effectively oxidises pollutants to less soluble compounds that are easily removed by sedimentation and filtration (Moturi and Singara-Charya, 2009). In addition, biological treatments are less expensive and environmentally-friendly.

However, challenges often encountered in large-scale utilization include the high cost of production, low yield and unstable enzymes. Thus, the solution lies in optimization of process parameters and utilization of suitable alternative substrates eg lignocellulose for cheap production of Total Soluble Protein (TSP) and enzymes in Solid State Fermentation Lignocellulose consist of lignin, cellulose and hemicelluloses and are the largest renewable source of carbohydrates that could undergo bioconversion to value-added products during fermentation. They are mostly 'waste products' of pre-harvest and post-harvest losses as a result of agricultural processing. They include saw-dust, grasses, waste paper, agricultural residues, food industry residues and municipal solid wastes. Apart from value-added products the process of bioconversion also removes wastes from the environment. It has been established that during fermentation nutrient utilization pathways of filamentous fungi influence metabolic diversity and allow fungi to utilize a variety of complex compounds as nutrients. For example, the growth of Aspergillus terreus, Trichoderma sp, Cyathus stercoreus, Lentinus squarrosulus, Lentinus edodes, Trametes pubescens, Pleurotus sp, Penicillium camemberti, Phanerochaete chrysosporium at $25-35^{\circ} \mathrm{C}$ for $3-22$ days resulted in $45-75 \%$ and $65-80 \%$ holocellulose and lignin degradation, respectively using lignocellulosic substrate (Mtui, 2009).

Due to diverse applications of bioproteins such as laccases and the high cost of production coupled with low yields and stability it is important to identify new sources with high production. The use of cheap alternative substrates such as saw-dust would lower the cost and enhance large-scale production both for commercial purposes and applications in enzymatic degradation of synthetic dyes and other xenobiotics currently employed in different industries. The objective of our study was to meet the demand for low-cost bioprotein production by Trametes sp. isolate B7 through optimization of process parameters and utilization of same for enzymatic degradation of synthetic dyes.

\section{MATERIALS AND METHODS}

\section{Substrate collection and processing}

Wood samples of Terminalia superba were collected from Gboko plank market Benue State, Nigeria. Samples were passed through an electric sliding-table saw machine to obtain wood blocks which were oven dried to constant weight at $80^{\circ} \mathrm{C}$. The blocks were directly fed into a motorized rotary machine and crushed into saw-dust particles. The saw-dust was then passed through a $2 \mathrm{~mm}$ wire mesh of metallic sieve to obtain particles of even sizes and thereafter dispensed into plastic bags and sealed.

\section{Isolation and Identification of fungus}

The fungus was isolated from a decaying wood in Benue Polytechnic Campus, Ugbokolo, Benue State, Nigeria. Pieces of sample were aseptically transferred onto sterile Potato Dextrose Agar (PDA) plates and incubated at $27 \pm 2{ }^{\circ} \mathrm{C}$ for 7 days. Pure cultures were obtained by sub-culturing onto fresh sterile PDA plates and were thereafter placed on PDA slants for refrigeration at $4^{\circ} \mathrm{C}$. Five-day old fungal cultures on PDA plates were observed for both cultural and morphological characteristics (Domsch et al., 2007). The fungal isolate was identified using molecular and phylogenetic characterization as described in Ado et al. (2018) The sequence was deposited in GenBank under the accession number MK024175.

\section{Production of growth medium}

The Lignin Modifying Medium (LMM) used to moisten the saw-dust sample had the following composition $\left(\mathrm{gL}^{-1}\right)$ glucose $10 \mathrm{~g}$, Ammonium tartrate $2 \mathrm{~g}, \mathrm{KH}_{2} \mathrm{PO}_{4}$ $1 \mathrm{~g}, \mathrm{MgSO}_{4} .7 \mathrm{H}_{2} \mathrm{O} 0.5 \mathrm{~g}, \mathrm{KCl} 0.5 \mathrm{~g}$, Yeast extract $1 \mathrm{~g}$, Soy tone $5 \mathrm{~g}, \mathrm{CuSO}_{4} .5 \mathrm{H}_{2} \mathrm{O}$ $(150 \mu \mathrm{m})$, EDTA $0.5 \mathrm{~g}, \mathrm{FeSO}_{4} 0.2 \mathrm{~g}, \mathrm{ZnSO}_{4} 0.01 \mathrm{~g}, \mathrm{MnCl}_{2} .4 \mathrm{H}_{2} \mathrm{O} 0.003 \mathrm{~g}, \mathrm{H}_{3} \mathrm{BO}_{4}$ $0.03 \mathrm{~g}, \mathrm{CoCl}_{2} .6 \mathrm{H}_{2} \mathrm{O} 0.02 \mathrm{~g}, \mathrm{CuCl}_{2} .2 \mathrm{H}_{2} \mathrm{O} 0.001 \mathrm{~g}, \mathrm{Na}_{2} \mathrm{MoO}_{4} .2 \mathrm{H}_{2} \mathrm{O} 0.003 \mathrm{~g}$ (Poojary et al., 2012)

\section{Solid state fermentation of total soluble protein}

Ten millilitres of the moistening medium was added to $100 \mathrm{~g}$ of the saw-dust with approximately $70 \%$ moisture content in $250 \mathrm{~mL}$ Erlenmeyer flask and sterilized by autoclaving at $121^{\circ} \mathrm{C}$ for 20 minutes. One percent $(\mathrm{w} / \mathrm{v})$ aqueous glucose solution was separately autoclaved at $110^{\circ} \mathrm{C}(10 \mathrm{psi})$ for 10 minutes and 2 $\mathrm{mL}$ aseptically added to the fermenting flask (Gomes et al., 2009). The flask was allowed to cool and inoculated with two $5 \mathrm{~mm}$ agar plugs of actively growing mycelia from 5-day old fungi cultures on PDA and incubated for 18 days. Each experiment was carried out in duplicate.
Optimization of total soluble protein and laccase activity

\section{Extraction and determination of total soluble protein}

Total soluble protein was extracted by addition of $100 \mathrm{~mL} 0.1 \mathrm{M}$ citratephosphate buffer ( $\mathrm{pH}$ 5.0) into the fermenting flask. The mixture was stirred with a glass rod for 30 minutes and filtered with cheese-cloth to remove saw-dust and fungal mycelia. The crude filtrate was then filtered with $90 \mathrm{~mm}$ Whatman No. 1 Filter paper to obtain a clear filtrate which was refrigerated at $4^{\circ} \mathrm{C}$. Protein concentration was quantified using the method of Lowry et al. (1951) and the standard curve obtained by plotting various concentrations of Egg albumin (BDH).

\section{Effect of pH on total soluble protein and laccase activity}

The $\mathrm{pH}$ of the moistening medium was adjusted to $\mathrm{pH}$ values ranging from 3.0 8.0 before sterilization and the general procedure carried out as earlier described in solid state fermentation of total soluble protein. After inoculation the flasks were incubated at $27 \pm 2^{\circ} \mathrm{C}$ for 18 days (Urairuj et al., 2003; Sivakumar et al., 2010).

\section{Effect of temperature on total soluble protein and laccase activity}

The fermenting flasks were moistened with the medium $(\mathrm{pH} 5.0$ ) before sterilization and the general procedure repeated as described in solid state fermentation of TSP. Incubation was carried out at $15^{\circ} \mathrm{C}, 25^{\circ} \mathrm{C}, 35^{\circ} \mathrm{C}$, and $45^{\circ} \mathrm{C}$ for 18 days (Urairuj et al., 2003).

Effect of copper and calcium ions on total soluble protein and laccase activity

The effect of metal ions was determined by adding $10 \mathrm{~mL}$ of $1,2,3,4$ and $5 \mathrm{mM}$ $\mathrm{Ca}^{2+}$ and $\mathrm{Cu}^{2+}$ solutions in their chloride forms; separately, 48 hours for stability before addition of the moistening medium (Wuyep et al., 2003). The general procedure was performed at $\mathrm{pH} 5.0$ and incubation carried out at $27 \pm 2{ }^{\circ} \mathrm{C}$ for 18 days.

Effect of ammonium sulphate and ammonium chloride on total soluble protein and laccase activity

The effect of nitrogenous sources was determined by substituting $2 \mathrm{~g} / \mathrm{L}$ ammonium tartrate with ammonium sulphate and ammonium chloride, separately in concentrations of $0.3,1.0,3.0$ and $6.0 \mathrm{~g} / \mathrm{L}$ and the medium adjusted to $\mathrm{pH} 5.0$. The general procedure was performed and incubation carried out at $27 \pm 2^{\circ} \mathrm{C}$ for 18 days (Urairuj $\boldsymbol{e t}$ al., 2003; Sivakumar $\boldsymbol{e t}$ al., 2010). The control was carried out using distilled water instead of $\left(\mathrm{NH}_{4}\right)_{2} \mathrm{SO}_{4}$ or $\mathrm{NH}_{4} \mathrm{Cl}$ solution.

Effect of different carbon sources on production of total soluble protein and laccase activity

The effect of different sugars on total soluble protein production and laccase activity was carried out by replacing $10 \mathrm{~g} / \mathrm{L}$ of glucose in the medium with equimolar concentration of the following sugars: lactose, sucrose, maltose and fructose (Singh and Abraham, 2013). The general procedure was performed at $\mathrm{pH} 5.0$ and incubation carried out at $27 \pm 2^{\circ} \mathrm{C}$ for 18 days.

\section{Effect of incubation time on production of total soluble and laccase activity}

The general procedure was performed at $\mathrm{pH} 5.0$ and incubation carried out at 27 $\pm 2^{\circ} \mathrm{C}$ for 6 - 34 days.

\section{Assay for laccase activity of total soluble protein}

Laccase activity was determined at $420 \mathrm{~nm}$ using 2, 2'-azino-bis (3-ethylbenzthiazoline-6-sulfonic acid) ABTS as described by Mtui and Masalu, (2008). One Unit of laccase activity was defined as activity of an enzyme that catalyzes the conversion of $1 \mu \mathrm{mol}$ of $\operatorname{ABTS}\left(\varepsilon=36,000 \mathrm{M}^{-1} \mathrm{~cm}^{-1}\right)$ per minute.

\section{Application of crude laccase in enzymatic degradation of synthetic dyes}

The decolourizing potential of crude laccase was tested using selected dyes at concentration of $0.01 \%(\mathrm{w} / \mathrm{v})$ dissolved in sterile distilled water. The reaction mixture consisting of equal volume aqueous solution of dye and crude protein of $1000 \mathrm{U} / \mathrm{mL}$ and $2000 \mathrm{U} / \mathrm{mL}(1: 1)$, separately, in citrate phosphate buffer (pH 5.0) was incubated at $27 \pm 2^{\circ} \mathrm{C}$ in the dark for $1,24,48,72$ and 120 hours. Decolourization of dyes was determined by monitoring the decrease in absorbance at the wavelength of maximum absorption for each dye: Phenol Red (475 nm), Congo Red (497 nm), Crystal Violet (590 nm), Remazol Brilliant Blue Royal (RBBR) $(587 \mathrm{~nm})$ and Malachite Green $(620 \mathrm{~nm})$ (Moturi and SingaraCharya, 2009; Stoilova et al., 2010). Control tests were performed using a heat- 
denatured crude enzyme. The experiment was carried out in triplicates and activity of decolourization calculated thus:

$$
\mathrm{D} \%=100 \times \frac{\left(A_{\text {ini }}-A f_{\text {in }}\right)}{A_{\text {ini }}}
$$

Where

$\mathrm{D}=$ Decolourization

$A_{\text {ini }}=$ Initial absorbance.

$\mathrm{A}_{\text {fin }}=$ Final absorbance of dye after incubation time.

(Moturi and Singara-Charya, 2009).

\section{Statistical analysis}

Results obtained from this study were subjected to analysis of variance using one way ANOVA and differences between means were separated by Duncan Multiple Range Test (Duncan, 1955).

\section{RESULTS AND DISCUSSION}

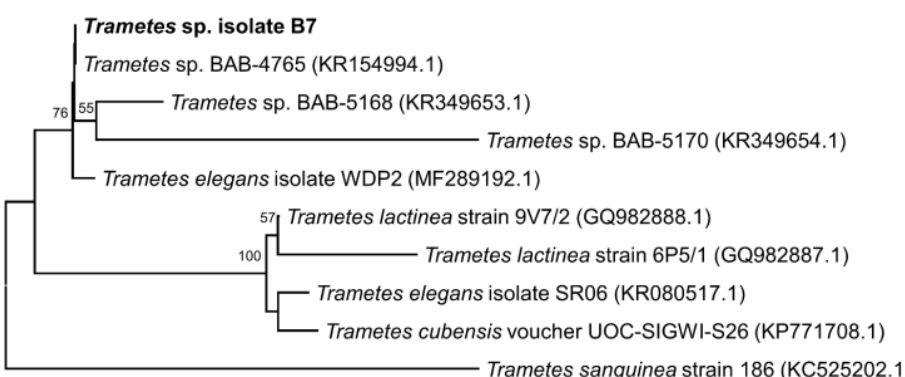

In the study, the optimum $\mathrm{pH}$ for production of total soluble protein by Trametes sp. isolate B7 was pH 5.0 with $3.6 \mathrm{mg} / \mathrm{mL}$ followed by $\mathrm{pH} 3.0$ and $\mathrm{pH} 7.0$ each with $3.2 \mathrm{mg} / \mathrm{mL}$, respectively. Equally, laccase activity followed the same pattern with the best production of $2356 \mathrm{U} / \mathrm{mL}$ at $\mathrm{pH} 5.0$ followed by $\mathrm{pH} 3.0$ and $\mathrm{pH} 7.0$ as shown in Figure 1. This showed that the optimum $\mathrm{pH}$ for TSP production coincided with the highest laccase activity. This agreed with the study that microbial proteins are produced in higher yield at a $\mathrm{pH}$ near to the optimum for enzyme production (Chanakya et al., 2010). Sivakumar et al. (2010) also reported the critical effect of $\mathrm{pH}$ on culture medium as its affects growth and secretion of bioproteins but stated that the optimum varies according to microorganisms. Several works have shown that the production of enzyme by fungal strains is best at $\mathrm{pH} 4-6$ while others placed the range at $\mathrm{pH} 3.5-7.0$ (Sivakumar et al., 2010; Singh and Abraham, 2013). The optimum $\mathrm{pH}$ for production of bioproteins and enzyme activity as shown in the study was within the range reported by other researchers. It is important to note that the actual $\mathrm{pH}$ optimum for fungal growth and secretion of TSP is specie and strain-specific coupled with the nature of lignocellulosics used in addition to the concentration of hydrogen ions present in the medium (Elisashvili and Kachlishvili, 2009; Chanakya et al., 2010).

The effect of temperature on total soluble protein production and laccase activity is presented in Figure 2. Result indicates that both total soluble protein production and laccase activity were best at $25^{\circ} \mathrm{C}$ with $2.3 \mathrm{mg} / \mathrm{mL}$ and 2395 $\mathrm{U} / \mathrm{mL}$ respectively. However, protein production and enzyme activity declined steadily with increase in temperature. It has been reported that Trichoderma koningii secreted maximum amount of soluble protein in $\mathrm{SSF}$ at $33^{\circ} \mathrm{C}$ while optimum production of soluble protein by Xylariaceae occurred at $30^{\circ} \mathrm{C}$ (Urairuj et al., 2003; Chanakya et al., 2010). The difference is probably due to differences in fungal species. Similarly, reports on the effect of temperature on laccase production showed the temperature range of $25-30^{\circ} \mathrm{C}$ as optimum for laccase production by Trametes sp., Pleurotus sp. and Dichomitus squalens (Iqbal et al., 2011) which goes in line with the study. In addition, the optimum temperature for fungal growth and production of enzymatic and non-enzymatic proteins lies close to the temperature in its natural habitat. At these temperatures fungi membranes are highly permeable while the synthetic machinery function at its peak; consequently, the rate of substrate conversion reaches its maximum (Bhattacharya et al., 2011). However, higher temperatures tend to denature metabolic activities such as fatty acid synthesis and membrane fluidity resulting to decrease in production (Schulte, 2015).

Figure 3 present the effects of $\mathrm{Cu}^{2+}$ ions on total soluble protein production and laccase activity. Results show that $\mathrm{Cu}^{2+}$ stimulated high laccase activity at $1-2$ $\mathrm{mM}$ with $2379 \mathrm{U} / \mathrm{mL}$ followed by a sudden decline at $3-5 \mathrm{mM}$ concentration while total soluble protein production was high at $3 \mathrm{mM}$ with $2.70 \mathrm{mg} / \mathrm{mL}$ but declined at 4 - 5 mM. Stajia et al. (2007) and Kumar et al. (2011) reported the regulatory effects of copper on transcription of genes for laccase production in addition to the inhibition of extracellular proteases that degrade laccases resulting to increased turnover in soluble protein production as well as laccase activity and stability. Stajia et al. (2007) reported the stimulatory effect of $1 \mathrm{mM}$ copper chloride on production of laccase by Trametes pubescens but placed the optimal concentration at $1.5-2.0 \mathrm{mM}$ which coincided with our result. However, as concentration increased above the threshold $\mathrm{Cu}^{2+}$ ion became toxic resulting in decreased laccase activity and soluble protein production as shown in the study. The effect of $\mathrm{Ca}^{2+}$ on total soluble protein production and laccase activity is shown in Fig. 4. Results indicate high laccase activity of $2379 \mathrm{U} / \mathrm{mL}(1 \mathrm{mM})$, $2365 \mathrm{U} / \mathrm{mL}(2 \mathrm{mM})$ and $2385 \mathrm{U} / \mathrm{mL}$ at $3-4 \mathrm{mM}$. The fungus was able to secrete high amounts of laccase on both low and high concentrations of $\mathrm{Ca}^{2+}$ because it improved the extracellular structure of the fungal proteins by acting as stabilizers (Wuyep et al., 2003). However, production of total soluble protein was generally lower than $\mathrm{Cu}^{2+}$ ion but more stable because of the stabilizing effect of the metal ion on extracellular proteins.

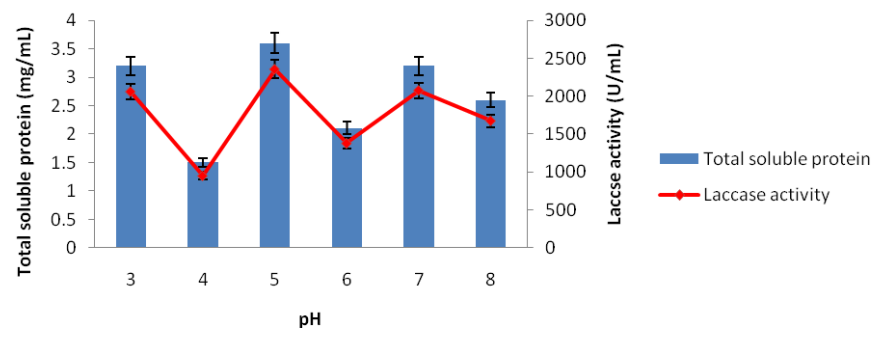

Figure 1 Effect of $\mathrm{pH}$ on production of total soluble protein and laccase activity. Bar represent standard error of the mean.

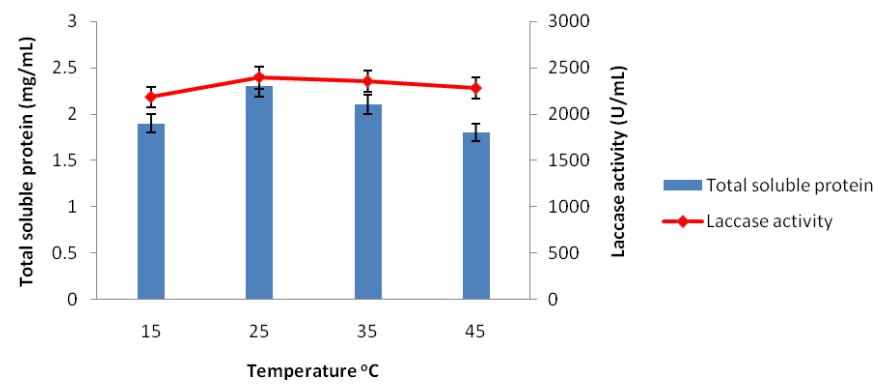

Figure 2 Effect of temperature on production of total soluble protein and laccase activity. Bar represent standard error of the mean.

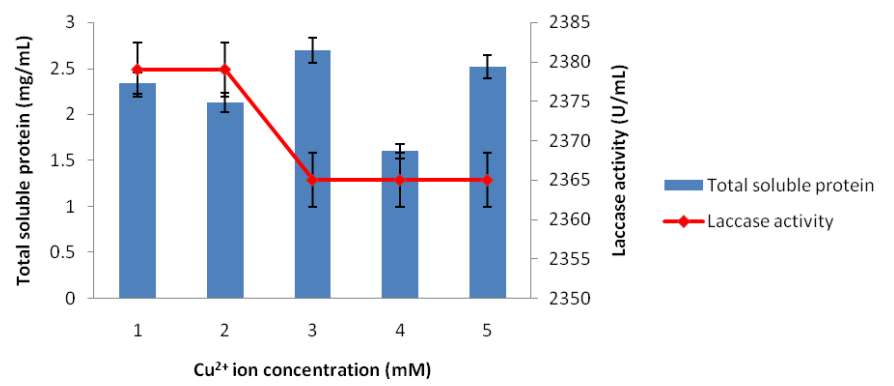

Figure 3 Effect of copper ions concentration on total soluble protein production and laccase activity. Bar represent standard error of the mean.

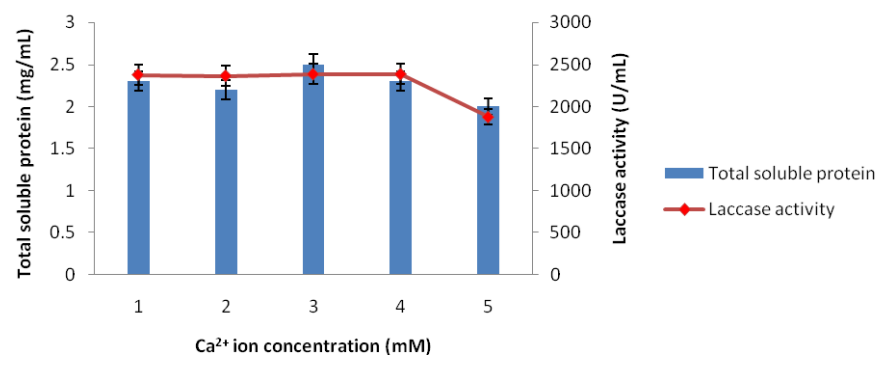

Figure 4 Effect of calcium ions concentration on total soluble protein production and laccase activity. Bar represent standard error of the mean.

The study investigated the effect of ammonium chloride and ammonium sulphate on total soluble production and laccase activity as presented in Figure 5. Production of total soluble protein was high in ammonium sulphate supplemented medium with $2.14 \mathrm{mg} / \mathrm{mL}$ as to $1.44 \mathrm{mg} / \mathrm{L}$ by ammonium chloride, while laccase activity was high using ammonium chloride supplemented medium with 2024 $\mathrm{U} / \mathrm{mL}$ but drastically low in ammonium sulphate with $277 \mathrm{U} / \mathrm{mL}$. Other authorities also reported maximum laccase activity with ammonium chloride using Coriolus versicolor and Pleurotus ostreatus instead of ammonium sulphate 
(Elsayet et al., 2012). On the contrary, another work showed maximum laccase production with ammonium sulphate using Trametes hirsuta MTCC 11397 (Dhakar and Pandey, 2013).

Figure 6 shows the effect of different carbon sources on total soluble protein production and laccase activity. Carbon sources appear to regulate the production of bioproteins in fungi but the source is specie specific. In this study, glucose was best for production of total soluble protein with $3.6 \mathrm{mg} / \mathrm{mL}$ followed by fructose, maltose and lactose while sucrose was the lowest with $1.5 \mathrm{mg} / \mathrm{mL}$. Significant production of laccase by $T$. pubescens has been reported on glucose and cellobiose while Pleurotus sajoro-caju produced higher amounts of laccase on glucose and fructose than lactose (Elisashvili and Kachlishvilli, 2009). In the study, laccase activity was best on glucose and lactose with $2395 \mathrm{U} / \mathrm{mL}$ and 1838 $\mathrm{U} / \mathrm{mL}$ but lowest on fructose with $809 \mathrm{U} / \mathrm{mL}$. Revankar and Lele (2006) in his work also stated that production of laccase by Pleurotus ostreatus was highest on glucose and starch but lowest on fructose. Also, Ding $\boldsymbol{e t}$ al. (2012) reported increased laccase production on glucose compared to maltose, sucrose, lactose and starch. It is evident that this variation in carbon sources was probably due to specie specificity and differences in substrate utilization.

Figure 7 presents result of the effect of incubation time on total soluble protein production and laccase activity. Production of total soluble protein increased from day 6 with $0.9 \mathrm{mg} / \mathrm{mL}$ to its peak on day 14 with $3.6 \mathrm{mg} / \mathrm{mL}$. Thereafter, production declined progressively for the remaining days of incubation. Many authors have reported different incubation periods for optimum production of crude enzymes. Das et al. (2011) stated that $P$. ostreatus produce the highest quantity of crude laccase on the $25^{\text {th }}$ day of incubation. On the contrary, Elisashvili et al. (2008) and Sivakumar et al. (2010) reported maximum laccase production on the $7^{\text {th }}$ and $10^{\text {th }}$ day of incubation using Lentinus edodes and Ganoderma sp, respectively; while Ding et al. (2012) reported maximum laccase production on the $11^{\text {th }}$ day with rubber wood saw-dust. Another work maintained that depending on the fungal strain and culture medium the peaks of laccase production varies from 5 - 14 days of incubation (Elisashvili and Kachlishvilli, 2009). From this study the peak of total soluble protein was day 14 while the peak for laccase activity was day 18 with $2395 \mathrm{U} / \mathrm{mL}$. Aftab and Ahmad (2015) reported maximum production of laccase by Ganoderma lucidum on day 16 which lies close to our study. The difference in peaks of laccase activity was probably based on differences in fungi species and the type of lignocellulosic substrate (Elsayet et al., 2012).

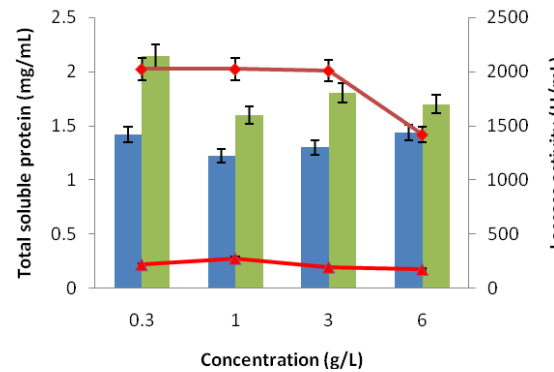

Toatal soluble protei Ammonium chloride)

Total soluble protein (Ammonium sulphate)

- Laccase activity (Ammonium chloride) - Laccase activity (Ammonium
sulphate)

Concentration (g/L)

Figure 5 Effect of different concentrations of ammonium chloride and ammonium sulphate on total soluble protein production

and laccase activity. Bar represent standard error of the mean.

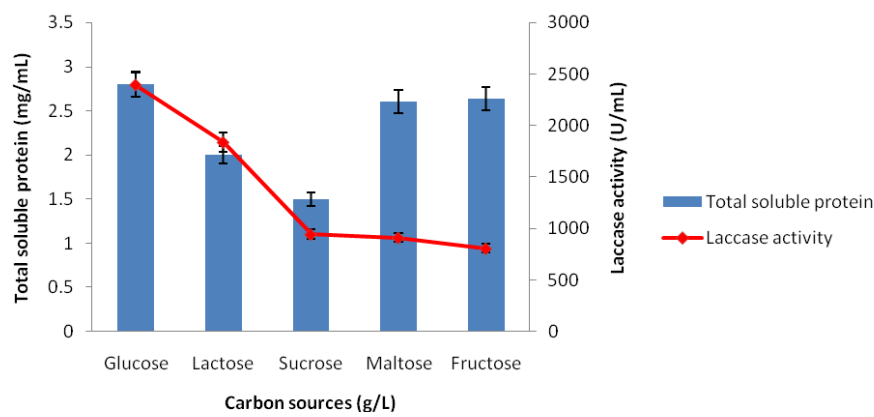

Figure 6 Effect of different carbon sources on production of total soluble protein and laccase activity. Bar represent standard error of the mean.

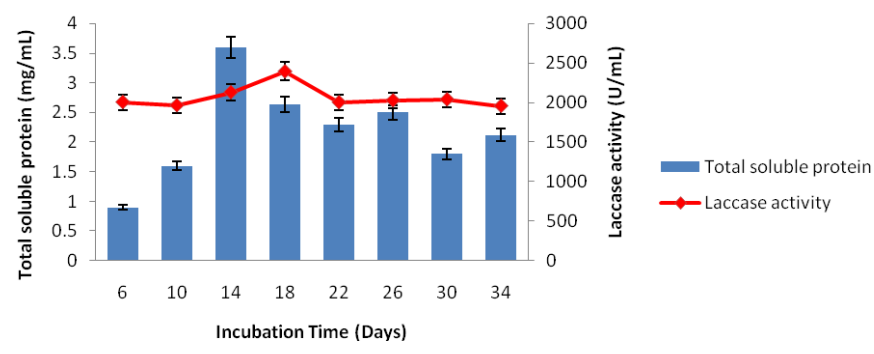

Figure 7 Effect of incubation time on production of total soluble protein and laccase activity. Bar represent standard error of the mean.

The ability of fungi to decolourize dyes has been reported in a number of isolates including $T$. versicolor. In this study, crude protein from Trametes sp. isolate B7 enzymatically degraded synthetic dyes of diverse structures as shown in Fig. 8 Phenol red attained $28 \%$ and $36 \%$ degradation using $1000 \mathrm{U} / \mathrm{mL}$ and $2000 \mathrm{U} / \mathrm{mL}$ crude protein respectively after 48 hours of incubation. The ability of the crude protein to degrade Phenol red without the use of mediators is an important characteristic since Phenol red has a high oxidation potential. This suggests that the crude enzyme possessed the capacity to oxidize a wide range of substrates (Saparrat et al., 2002). Nevertheless, with prolonged incubation of 72 to 120 hours the extent of enzymatic degradation dropped. This is because enzymatic degradation of dyes is a multi-step process that involves a decrease in absorbance of the visible peak at the beginning. However, after 72 hours there is a general increase in absorbance due to polymerization of dye fragments resulting in darker solutions (Zille et al., 2005).

The extent of degradation of RBBR, Congo red and Malachite green were $100 \%$, $75 \%$ and $62 \%$ using $1000 \mathrm{U} / \mathrm{mL}$ crude protein and $77.4 \% 64 \%$ and $28 \%$ using $2000 \mathrm{U} / \mathrm{mL}$ crude protein respectively. The degree of decolourization was not the same in all the dyes probably due to the enzyme concentrations, their substrate specificity as well as the complex structure of many of the synthetic dyes (Poojary et al., 2012). In a study, 100\% of RBBR was decolourized in 6 hours and Congo red in 13 days using $2000 \mathrm{U} / \mathrm{mL}$ crude laccase of $T$. versicolor (Stoilova et al., 2010). Interestingly, crude protein containing laccase from Trametes sp. isolate B7 decolourized $100 \%$ of RBBR in 24 hours and $75 \%$ of Congo red within 72 hours of this study. These differences are attributed to the fact that the redox potential of enzymes varies with the source which could determine the need of mediators for decolourization of specific dyes (Stoilova $\boldsymbol{e t}$ al., 2010). Reports indicate that crude laccase from L. polychrous decolourized Rhodamine B and Congo red using the mediator ABTS (Suwannawong et al. 2010). However, this study showed that crude laccase from Trametes sp. isolate B7 decolourized $75 \%$ Congo red without any enzyme mediators. More so, the crude laccase was able to decolourize Congo red unlike crude laccases from $P$. radiata strain BP-11-2, which failed to decolourize the dye (Suwannawong $\boldsymbol{e t}$ al., 2010).

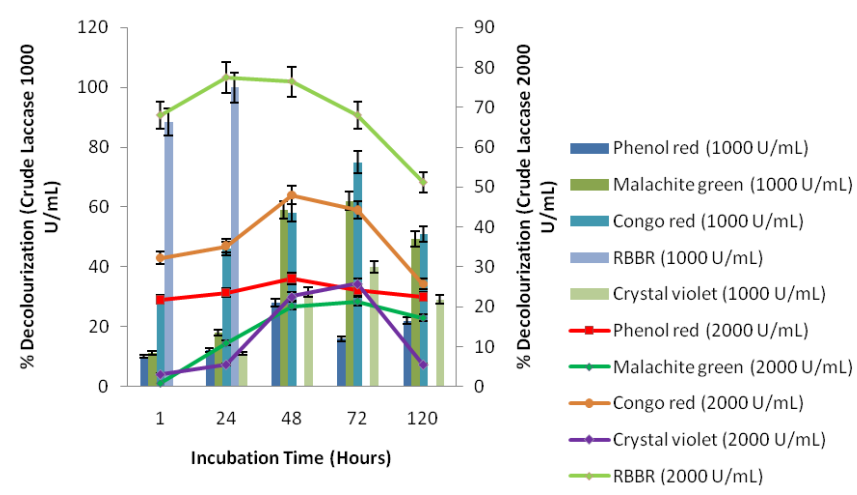

Figure 8 Percentage decolourization of synthetic dyes using $1000 \mathrm{U} / \mathrm{mL}$ and 2000 $\mathrm{U} / \mathrm{mL}$ crude enzymes.

Bar represent standard error of the mean.

\section{CONCLUSION}

Optimization of cultural and nutritional factors for the production of TSP and increased laccase activity by Trametes sp. isolate B7 using saw-dust of Terminalia superba proved very useful in TSP production and enzymatic degradation of different synthetic dyes. Temperature had the most profound effect on laccase activity with optimum at $25^{\circ} \mathrm{C}(2395 \mathrm{U} / \mathrm{mL})$ while $\mathrm{pH} 5.0$ was optimum for TSP production $(3.6 \mathrm{mg} / \mathrm{mL}) . \mathrm{Ca}^{2+}$ and $\mathrm{Cu}^{2+}$ showed considerable influence on laccase activity at $3-4 \mathrm{mM}(2385 \mathrm{U} / \mathrm{mL})$ and $1-2 \mathrm{mM}(2379)$ respectively. Glucose was the preferred source of carbon both for TSP production 
and laccase activity. Ammonium chloride favoured high laccase activity and ammonium sulphate enhanced higher TSP production. Effect of incubation time showed optimum production of TSP on day 14 and laccase activity on day 18 . In the study, the extent of enzymatic degradation of RBBR, Phenol red, Congo red and Malachite green by crude laccase $1000 \mathrm{U} / \mathrm{mL}$ were $100 \%, 28 \%, 75 \%$ and $62 \%$ respectively. Enzymatic degradation of RBBR, Phenol red, Congo red and Malachite green by crude laccase $2000 \mathrm{U} / \mathrm{mL}$ were $77 \%, 36 \%, 64 \%$ and $28 \%$ respectively. The ability of crude enzyme to degrade all the dyes including Phenol red without enzyme mediators is important. In addition the structural similarity of the dyes to many recalcitrant compounds and the extended substrate range makes the enzyme a suitable candidate for several industrial and biotechnological applications.

\section{REFERENCES}

ADO, B.V., ONILUDE, A.A., AMANDE, T. 2018. Production and optimization of laccase by Trametes sp. isolate B7 and its' dye decolourization potential. Journal of Advances in Microbiology, 13(1), 1 - 14 http://dx.doi.org/10.9734/JAMB/2018/44218.

AFTAB, Z.H., AHMAD, S. 2015. Ganoderma lucidum: A case study for laccase biosynthesis. Pakistan Journal of Phytopathology, 27(1), $95-103$.

BENEYTON, T., WIJAYA, I.P.M., POSTROS, P., NAJAH, M., LEBLOND, P. COUVENT, A., MAYOT, E., GRIFFITHS, A.D., DREVELlE, A. 2016. Highthroughput screening of filamentous fungi using nanoliter range droplet based microfluidics. Scientific Reports, https://dx.doi.org/10.1038/SREP27223.

BHATTACHARYA, S., BHARDWAJ, S., DAS, A., ANAND, S. 2011 Utilization of sugar cane bassage for solid state fermentation and characterization of $\alpha$-amylase from Aspergillus flavus Isolated from Muthupettai mangrove, Tamil Nadu. Australian Journal of Basic and Applied Sciences, 5(12), 1012 - 1022. CHANAKYA, P., MANIPATI, S., SOMALANKA, S. R. 2010. Process optimization of L-glutaminase production by Trichoderma koningii under solid state fermentation. Journal of Applied Biology and Pharmaceutical Techonolgy, 3, $1168-1174$.

DAS, N., NASKAR, S., CHOWDHURY, P., PASMAN, B., ADHIKARI, D 2011. Experimental evidence for presence of a growth regulating extracellular laccase in some Pleurotus species. Research Journal of Microbiology, 6, 496 502 .

DHAKAR, K., PANDEY, A. 2013. Laccase production from a temperature and pH tolerant fungal strain of Trametes hirsuta (MTCC 11397). Enzyme Research 2013, 1 - 9. http://dx.doi.org/10.1155/2013/869062.

DING, Z., PENG, L., CHEN, Y., ZHANG, L., GU, Z., SHI, V., ZHANG, K. 2012. Production and characterization of thermostable laccase from the mushroom, Ganoderma lucidum, using submerged fermentation. African Journal $\begin{array}{lllll}\text { of } & \text { Microbiology } & \text { Research, } & 6(6), & 1147\end{array}$ http://dx.doi.org/10.5897/AJMR11.1257.

DOMSCH, K. H., GAM, W., ANDERSON, T. H. 2007. Compendium of Soil Fungi, $2^{\mathrm{ND}}$ ED., IHW-Verlag, Eching, Germany.

DUNCAN, D.B. 1955. Multiple range and multiple F tests. BIOMETRICS, 11, 1 $-42$.

ELISASHVILI, V., KACHLISHVILI, E. 2009. Physiological regulation of laccase and manganese peroxidase production by White-Rot Basidiomycetes. Journal of Biotechnology, 144, 37 - 42.

ELISASHVILI, V., PENNINCKX, M., KACHLISHVILI, E., TSIKLAURI, N., METREVELI, E., KHARZIANI, T., KVESITADZE, G. 2008. Lentinus edodes and Pleurotus species lignocellulolytic enzymes activity in submerged and solidstate fermentation of lignocellulosic wastes of different composition. Bioresouces Technology, 99, 457 - 462.

ELSAYED, M.A., HASSAN, M.M., ELSHAFEI, A.M., HAROUN, B.M., OTHMAN, A.M. 2012. Optimization of cultural and nutritional parameters for the production of laccase by Pleurotus ostreatus ARC280. British Biotechnology Journal, 2(3), 115 - 132.

FALLAH, A.A., BARANI, A. 2014. Determination of malachite green residues in farmed rainbow trout in Iran. Food Control, 40, $100-105$ http://dx.doi.org/10.1016/j.foodcont.2013.11.045.

GOMES, E., AGUIAR, A.P., CARVALHO, C.C., BONFA, M.R.B., SILVA, R. BOSCOLO, M. 2009. Ligninase production by basidiomycetes strains on lignocellulosic agricultural residues and their application in the decolourization of synthetics dyes. Brazilian Journal of Microbiology, 40, 31 - 39.

GONAWALAL, K.H., MEHTA, M.J. 2014. Removal of colour from different dye wastewater by using ferric oxide as an adsorbent. Journal of Engineering Research and Applications, 4(5), 102 - 109.

HASSAAN, M.A., NEMR, A.E. 2017. Health and environmental impacts of dyes: Mini Review. American Journal of Environmental Science and Engineering, 1(3), 64 - 67. http://dx.doi.org/10.11648/j.ajese.20170103.11.

IQBAL, H.M.N., ASGHER, M., BHATTI, H.N. 2011. Optimization of physical and nutritional factors for synthesis of lignin degrading enzymes by a novel strain of Trametes versicolor. Bioresources, 6(2), 1273 - 1287.

ITODO, A.U., OKETUNDE, F.K. 2017. Activated carbon: spent, regenerated and reuse for synthetic dyestuff effluent decolorization. International Journal of Environmental Monitoring and Protection, 4(4), 29 - 37.
KUMAR, V.V., KIRUPHA, S.D., PERIYARAMAN, P., SIVANESAN, S. 2011 Screening and induction of laccase activity in fungal species and its application in dye decolorization. African Journal of Microbiology Research, 5(11), 1261 1267.

KUNAMNENI, A., CAMARERO, S., GARCÍA-BURGOS, C., PLOU, F.J., BALLESTEROS, A., ALCALDE, M. 2008. Engineering and applications of fungal laccases for organic synthesis. Microbial Cell Factories, 7, 32. http://dx.doi.org/10.1186/1475-2859-7-32.

LOWRY, O.H., ROSEBROUGH, N.J., FARR, A.L., RANDALL, R.J. 1951. Protein measurement with the folin phenol reagent. The Journal of Biological Chemistry, 193, 265 - 75.

MARTINS, S., MUSSATTO, S.I., MARTÍNEZ-AVILA, G., MONTAÑEZ SAENZ, J., AGUILAR, C.N., TEIXEIRA, J.A. 2011. Bioactive phenolic compounds: production and extraction by solid-state fermentation. A review. Biotechnology Advances, 29, 365 - 373.

MOTURI, B., SINGARA-CHARYA, M.A. 2009. Decolourization of crystal violet and malachite green by fungi. Science World Journal, 4 (4), 1597 - 6343.

MTUI, G. Y. S. 2009. Recent advances in pretreatment of lignocellulosic wastes and production mushroom development. Recent Research Developments in Microbiology, 7, 381 - 415 .

MTUI, G., MASALU, R. 2008. Extracellular enzymes from brown-rot fungus Laetiporus sulphureus isolated from mangrove forests of coastal Tanzania. Scientific Research and Essay, 3(4), 154 - 161.

POOJARY, H., HOSKERI, A., KAUR, A., MUGERAYA, G. 2012. Comparative production of ligninolytic enzymes from novel isolates of basidiomycetes and their potential to degrade textile dyes. Nature and Science, 10(10), 90 - 96.

REVANKAR, M.S., LELE, S.S. 2009. Increased production of extracellular laccase by the white rot fungus Coriolus versicolor MTCC 138. World Journal Microbiology \& Biotechnology, 22, 921 - 926.

ROUSHDY, M.M., ABDEL-SHAKOUR, E.H. 2011. Potential biotechnological application of lignin peroxidase produced by Cunninghamella elegans in the decolorization and detoxification of malachite green dye. New York Science Journal, 4(8), 80 - 88.

SAPARRAT, M.C.N., GUILLEN, F., ARAMBARRI, A.M., MARTINEZ, A.T., MARTINEZ, M.J. 2002. Induction, Isolation, and Characterization of Two Laccases from the White Rot Basidiomycete Coriolopsis rigida. Applied and Environmental Microbiology, 68(4), 1534 - 1540.

SCHULTE, P.M. 2015. The effects of temperature on aerobic metabolism: Towards a mechanistic understanding of the responses of ectotherms to a changing environment. The Journal of Experimental Biology, 218, 1856 - 1866. http://dx.doi.10.1242/JEB.118851.

SINGH, N., ABRAHAM, J. 2013. Isolation of laccase producing fungus from compost soil and partial characterization of laccase. Advances in Applied Science Research, 4(5), 91 - 98.

SIVAKUMAR, R., RAJENDRAN, R., BALAKUMAR, C., TAMILVENDAN, M. 2010. Isolation, screening and optimization of production medium for thermostable laccase production from Ganoderma sp. International Journal of Engineering Science and Technology, 2(12), 7133 - 7141.

SONGSERM, P., SIHANONTH, P., SANGVANICH, P., KARNCHANATAT, A. 2012. Decolorization of textile dyes by Polyporus pseudobetulinus and extracellular laccase. African Journal of Microbiology Research, 6(4), 779 - 792 http://dx.doi.10.5897/AJMR11.988.

STAJIA, M., VUKOJEVIA, J., LAUSEVIA, S.D. 2007. Influence of the cultivation conditions on ligninolytic enzyme production in Pleurotus pulmonarius. Proceedings Nature and Science, 113, 303 - 312

STOILOVA, I., KRASTANOV, A., STANCHEV, V. 2010. Properties of crude laccase from Trametes versicolor produced by solid-state fermentation. Advances in Bioscience and Technology, 1, 208 - 215.

SUWANNAWONG, P., KHAMMUANG, S., SARNTHIMA, R. 2010 Decolorization of rhodamine $\mathrm{B}$ and congo red by partial purified laccase from Lentinus polychrous Lev. Journal of Biochemistry and Technology, 2 (3), 182 186.

URAIRUJ, C., KHANONGNUCH, C., LUMYOUNG, S. 2003. Ligninolytic enzymes from tropical endophytic xylariaceae. Fungal Diversity, 13, $209-219$.

VILLEGAS, L.G.C., MASHHADI, N., CHEN, M., MUKHERJEE, D., TAYLOR, K.E., BISWAS, N. 2016. A short review of techniques for phenol removal from wastewater. Current Pollution Reports, 2(3), 157 - 167.

WUYEP, P.A., KHAN, A.U., NOK, A. J. 2003. Production and regulation of lignin degrading enzymes from Lentinus squarrosulus (mont.) Singer and Psathyrella atroumbonata Pegler. African Journal of Biotechnology, 2(11), 444 447.

ZILLE, A., GORNACKA, B., REHOREK, A., CAVACO-PAULO, A. 2005. Degradation of azo dyes by Trametes villosa laccase over long periods of oxidative conditions. Applied and Environmental Microbiology, 71(11), 6711 6718 